\title{
Internet Financial Reporting and Its Determinants
}

\author{
Azmi Fitriati ${ }^{1}$, Rina Mudjiyanti ${ }^{2}$, Widiati Indra Lestari ${ }^{3}$, Annisa Wafi Iftinan $^{4}$, Ailsa \\ Nadiyah Shabrina ${ }^{5}$ \\ \{azmi.fitriati@gmail.com ${ }^{1}$, rinamudjiyantie17@gmail.com², widiatilestari251@gmail.com ${ }^{3}$ \}
}

Departement of Accounting, Universitas Muhammadiyah Purwokerto, Purwokerto, Indonesia 1,2,3,4,5

\begin{abstract}
The purpose of this study is to examine the impact of profitability, liquidity, firm size, firm age, and leverage on internet financial reporting (IFR). The population used is the financial sector company listed on the Indonesia Stock Exchange (IDX) 20152018. Samples were taken using the purposive sampling technique. Data analysis using multiple regression. Regression models must fulfill several assumptions (normality, homoscedasticity, no multicollinearity, and no autocorrelation), F-test, and test of determination $\left(\mathrm{R}^{2}\right)$. Hypotheses testing using t-test with $\alpha(5 \%)$. The results of the study showed statistically profitability and leverage negatively affect IFR. Liquidity and firm size positively affect IFR. While statistically, the firm age does not affect IFR. Regression models can be used to predict the impact of profitability, liquidity, firm size, firm age, and leverage on IFR. Companies with low profitability or high leverage try to maintain their reputation by expanding the disclosure of other financial information through IFR. Companies that have good news want to immediately share it through IFR, otherwise if there is bad news.
\end{abstract}

Keywords: internet financial reporting, profitability, liquidity, firm size, firm age, leverage.

\section{Introduction}

In the era of globalization, most companies use network power and internet coverage to provide more useful financial information to readers [1]. The growth of internet technology allows the company to directly and quickly disclose their financial and non-financial information to meet the needs of users worldwide [2]. In the era of digital-based business, having a high quality and effective website has become one of the key strategic priorities for many organizations [3][4].

The company utilizes the benefits of the internet to provide useful information to users of financial statements [1]. The company is motivated to communicate information over the internet to gain benefits such as global marketing, minimize costs, communicate information more broadly, quickly and efficiently and to facilitate interactions with stakeholders [5].

According to Desoky [6], Internet Financial Reporting (IFR) is financial reporting through its website (internet). IFR benefits include low cost, wider range, reliable frequency, and speed. companies use IFR to communicate extensively with investors and other key stakeholders. IFR has become an important medium as a dynamic strategy, and it can be adapted to the needs of information for the wider audience in real-time [7].

Maulana and Almilia [8] stated there are $62 \%$ of companies listed on the Indonesia Stock Exchange (IDX) which already have a website to publish financial and non-financial information of the company. This indicates the practice of IFR in Indonesia but the quality or 
quantity of IFR has not been standardized [8]. The Indonesian Financial Accounting Standards Board has not set or endorsed the regulations on IFR [8].

Some studies have found several factors affecting IFR include profitability, liquidity, firm size, firm size, and leverage. According to Putri and Azizah [9], profitability is the company's ability to generate profit in a period. Companies will tend to reveal more information if profitability is high. Following the signal theory, companies that have a high level of profitability will strive to increase the influence in decision making of investors by attracting attention to stakeholders. The relationship shows that the higher the profitability rate, the broader the disclosure of website-based financial statements (IFR) [9].

Previous research on the effect of profitability on IFR has had different results. Several studies stated that profitability has a positive effect on IFR [9][10][11]. Companies with high profitability have more website-based financial statement disclosures. Other research stated that profitability has a negative effect on IFR [12][13]. According to Maulana and Almilia [8], Reskino and Sinaga [14], profitability does not affect internet financial reporting (IFR).

Another factor affecting IFR is liquidity. According to Fahmi [15], liquidity is the ability of a company to fulfill its short term obligations promptly. Companies with high liquidity will be more motivated to inform the financial report in full and wide compared to low liquidity companies [11]. Following the theory of signal, high liquidity is good news for the company so motivated to reveal the financial report promptly through IFR [16].

Previous research states that liquidity has a positive effect on internet financial reporting (IFR) [11][17]. Different results stated by Leonardi et al. [18] that liquidity has a negative effect on IFR. Other studies have stated that liquidity has no effect on IFR [8][12][19].

IFR is also influenced by firm size. Firm size is a value that shows the total assets, sales, and profits obtained [8]. The greater the total assets, sales, and profits, the greater the size of the company [8]. Large companies usually have more information than small companies. Consistent with agency theory, large companies disclose more information through IFR [20]. It aims to attract investors and minimize the occurrence of agency conflict between principal and agent [14]. Previous research results found firm size has a positive effect on IFR [9][12][20]. Different results stated that firm size has no effect on IFR [11][21][22].

Another factor affecting IFR is firm age. Firm age is based on the length of the company listed on the Indonesia Stock Exchange (IDX) [23]. Companies that have a longer life usually have more experience in reporting information through IFR. According to Harsanti et al. [24] older companies often provide more information through IFR. Previous research results found firm age had a positive effect on IFR [23][24][25]. This result is different from Jannah [22] which stated that firm age does not affect IFR.

Leverage also affect IFR. Leverage is the ratio used to measure the extent to which the company's activities are financed by debts. Companies that have high leverage have company activities that are mostly financed by debt [9]. The high level of leverage will make the company try to create a positive image for creditors, investors, and other stakeholders through IFR. Financial reporting through IFR not only discusses financial information but also information on social activities and other activities that can improve the company's image [9]. Based on agency theory, companies with high leverage in the capital structure will have higher agency costs. The company has a higher obligation to meet the interests of creditors and shareholders. The interest encourages the company to conduct broader information disclosure through the company's website (IFR) [26]. Leverage have a positive influence on IFR [9][26]. The results differed from Maulana and Almilia [8], Khikmawati and Agustina [19], Diatmika and Yadnyana [27]. They stated that leverage has a negative effect on IFR. Other results stated that leverage does not affect IFR [9][14]. 
Based on the background above with the inconsistency of previous research results, the issue formulation is proposed: examine the effect of profitability, liquidity, firm size, firm age, and leverage on internet financial reporting (IFR).

\section{Literature Review}

\subsection{Internet Financial Reporting}

IFR is the disclosure of financial information using the Internet through the website owned by the company [10]. IFR is a voluntary financial disclosure practice. The financial statements provided online have the same scale and scope as the print version. IFR can provide legitimate, complete, usable, transparent, and secure financial information for users [28].

IFR is measured by the IFR index. The index consists of four components and each component has its weightlessness. Maulana and Almilia [8] use the four components of the IFR index, which is (1) content (weight 40\%), including the balance sheet, profit loss, cash flow, changes in financial position and the company's sustainability report; (2) timeliness $(20 \%)$; (3) technology utilization (20\%); and (4) user support $(20 \%)$. The area of IFR is a wide disclosure of the company's financial statements through the internet (company website) [10]. The IFR area refers to the breadth of use of the company's website to disseminate financial performance information [28].

\subsection{Profitability and Internet Financial Reporting}

Profitability is the ratio used to measure management effectiveness based on the small level of profit earned [15][29]. According to Gibson [30], profitability is the ability of the company to earn a profit. This ratio is used to evaluate corporate profits based on sales, asset, or owner's investment [31]. Alarussi et al. [2]; Fahmi [15] explained gross profit margin (GPM), net profit margin (NPM), return on assets (ROA), return on equity (ROE) and return on investments (ROI) can be used to measure the profitability ratio.

Many studies have found a positive influence between profitability and IFR [32-38]. Companies with high profits will also be increasingly large companies doing IFR practices to publish good news [20][21][26]. Ahmed et al. [39] and Fathi [35] also stated that companies with high profitability publish more information about company performance. Disclosure of good news can enhance a company's reputation. Companies with high profitability have incentives to differentiate themselves from others [40] with more than information of strength and opportunity [41][42]. Otherwise companies with low profitability performance, the company will reduce information that will become bad news [9]. Based on the description, the proposed hypotheses was:

$\mathrm{H}_{1}$ : Profitability has positive effect on internet financial reporting

\subsection{Liquidity and Internet Financial Reporting}

Liquidity is the ability of a company to fulfill its short-term obligation promptly [15][29]. The liquidity measurement indicators are current ratio, quick ratio, net working capital ratio, net working capital ratio, and cash flow liquidity ratio [15].

Oyelere et al. [41], Almtairi [43], found liquidity as one of the main determinants of IFR. Liquidity has a positive effect on IFR. Companies with high liquidity will publish more information to differentiate themselves from other companies. High liquidity shows 
companies can perform operational activities [17]. Companies with high liquidity show good news, so the company wants to immediately disclose financial statements through IFR [16]. Based on the description, the proposed hypotheses was:

$\mathrm{H}_{2}$ : Liquidity has positive effect on internet financial reporting

\subsection{Firm Size and Internet Financial Reporting}

Firm size is a large size of a company's small amount based on total assets, total sales, stock market value, number of profits, tax expense, and others. Firm size can be measured in various ways, such as used capital, sales turnover, number of employees, market value, and others [2]. Many studies found that firm size affects IFR positively [2][41][44][45]. Firm size is often regarded as the determining factor for internet financial reporting [40][46-48]. Large companies will be motivated to use IFR because they have the ability to disclose more information at lower costs and convenience for users.

Other studies have also found firm size had a positive effect on IFR [49-52]. Large companies have a tendency to disclose higher quality information because of their high level of supervision [36]. Large companies have a high level of corporate complexity [14][20]. Business targets are increasing, business competition is tight, relations with the government and regulators are also getting tougher. Such complexity will encourage the company to disclose more information through company's website (IFR) to attract investors and minimize the occurrence of agency conflict [14]. Based on the description, the proposed hypotheses was:

$\mathrm{H}_{3}$ : Firm size has positive effect on internet financial reporting

\subsection{Firm age and Internet Financial Reporting}

Firm age is the length of a company standing [53]. Firm age is based on the length of the company already listed on the Indonesia Stock Exchange (IDX) [20]. Companies that have a longer age means having more experience in reporting information through IFR [24].

According to Owusu-Ansah [54][55], younger companies are less likely to disclose information as they may suffer losses if disclosing information such as research and development expenditure, capital expenditure, or new products. Otherwise, older companies will be more motivated to disclose this information. The disclosure is considered not to threaten their competitive position.

The longer the company's life, the more their information and experience can be published [53]. The longer the company's life, the more their information and experience can be published. The company has the possibility to change the method of reporting financial information in accordance with technological developments. it is a change in publishing information through IFR [25]. Previous research stated that firm age has a positive influence on internet financial reporting (IFR) [20][24][25]. Based on the description, the proposed hypotheses was:

$\mathrm{H}_{4}$ : Firm age has positive effect on internet financial reporting

\subsection{Leverage and Internet Financial Reporting}

Leverage is measuring how big the company is financed with debt [15]. The leverage ratio measures the proportion of debt in the capital structure. The indicators of measuring leverage include debt to total assets or debt ratio, debt to equity ratio, times interest earned, long-term debt to total capitalization, and fixed charge coverage [15]. 
Leverage has a positive effect on IFR [34][36][37][56]. Companies that have high levels of leverage mean having large debts. The company will publish more information to satisfy creditors [57]. The interest encourages the company to conduct more disclosure of information through the company's website (IFR) [26]. Companies with high leverage will provide more voluntary disclosure through IFR, to reduce agency costs and information asymmetry [2][41]. Debreceny et al. [46] and Boubaker et al. [58] argued that IFR can contribute to reducing agency problems, as it allows debtholders to be able to monitor the company effectively and receive timely information.

Companies with high leverage have more financial costs, and creditors demand to be informed. Damaso and Lourenco [59] argued that a high-leverage company seeks to make broader disclosures through IFR to benefit from such disclosures. the company considers IFR to be a potential means to facilitate monitoring by creditors [60]. Based on the description, the proposed hypotheses was:

$\mathrm{H}_{5}$ : Leverage has a positive effect on internet financial reporting

\section{Method}

This type of research is quantitative research to test the impact of profitability, liquidity, firm size, firm age, and leverage on internet financial reporting (IFR). The financial sector companies listed on the Indonesia Stock Exchange (IDX) 2015-2018 as the research population. Samples were taken using the purposive sampling technique (176 samples).

The research variables include internet financial Reporting (IFR) as the dependent variable. Profitability, liquidity, firm size, firm age, and leverage as independent variables. Variable operational definitions are presented in table 1.

Table 1. Variables and indicators

\begin{tabular}{cc}
\hline Variables & Indicators \\
\hline Profitability & ROA $=\frac{\text { Earning After Tax }}{\text { Total Assets }}$ \\
Liquidity & $\mathrm{CR}=\frac{\text { Current Asset }}{\text { Current Liabilities }}$ \\
Firm Size & Firm Size $=$ Ln (Total Assets) \\
Firm Age & Firm Age $=$ Age of the company since incorporation \\
Leverage & DER $=\frac{\text { Total Liabilities }}{\text { Total Shareholder's Equity }}$ \\
Internet Financial Reporting & IFR Indeks $=\frac{\Sigma \text { Score of the Individual Company }}{\Sigma \text { Maximal Scores }}$ \\
\hline
\end{tabular}

Data analysis using multiple regression. Regression models must fulfill the testing of classic assumptions (normality, homoscedasticity, no multicollinearity, and no autocorrelation), F-test, and test of determination $\left(\mathrm{R}^{2}\right)$. Hypotheses testing using t-test with $\alpha$ $(5 \%)$.

\section{Result And Discussion}

The descriptive statistical results of the profitability, liquidity, firm size, firm size, leverage, and IFR variables are presented in Table 2. 
Table 2. Descriptive Statistic

\begin{tabular}{lccc}
\hline \multicolumn{1}{c}{ Variables } & Minimum & Maximum & Mean \\
\hline Profitability & -0.11 & 0.11 & 0.02 \\
Liquidity & 0.05 & 13.18 & 1,56 \\
Firm Size & 26.6 & 34.8 & 31,16 \\
Firm Age & 0.00 & 107.0 & 16,88 \\
Leverage & 0.19 & 285.2 & 25,96 \\
IFR & 0.57 & 0.87 & 0,75 \\
\hline
\end{tabular}

Table 2 shows the sample companies have an average profitability of 0.02 or $2 \%$. This value means the profit generated by the company is $2 \%$ of the total assets. The average liquidity is 1.56 or $156.6 \%$. This means that the average company has greater current assets than its current debt. The sample is a large company with an average age of 16 years. The average leverage is 25.96 (greater than 1.00). This means that the company has a total liability greater than total equity. Internet financial reporting (IFR) disclosure of $75 \%$. It shows a lot of information published through IFR

Regression models must fulfill the classic assumption testing. It includes tests of normality, heteroscedasticity, multicollinearity and autocorrelation. The results of testing classic assumptions are presented in Table 3.

Table 3. Assumptions of multiple linear regression

\begin{tabular}{lccc}
\hline \multicolumn{1}{c}{ Test-instrument } & Result & Standard & Conclusion \\
\hline Normalitas - One Sample & Asymp. Sig. (2-tailed) $=0.200$ & $>0.05$ & normally \\
Kolmogorov-Smirnov Test & distributed \\
& Sig. (Profitability) $=0.33$ & & No \\
Heteroscedasticity - glejser & Sig. (Liquidity) $=0.35$ & & heteroscedasticity \\
test & Sig. (Firm Size) $=0.08$ & $>0.05$ & \\
& Sig. (Firm Age) $=0.24$ & & No \\
& Sig. (Leverage) $=0.96$ & & multicollinearity \\
VIF (Profitability) $=1.39$ & & \\
Multicollinearity - VIF & VIF (Liquidity) $=2.45$ & & No \\
& VIF (Firm Size) $=1.15$ & & autocorrelation \\
Autocolerration - Durbin- & VIF (Firm Age) $=1.18$ & & dU \\
Watson & VIF (Leverage) $=2.86$ & $\mathrm{~d}<4-$ & \\
\hline
\end{tabular}

Based on Table 3 the classic assumption tests are all fulfilled. It shows that regression models have used normally distributed data, no heteroscedasticity, multicollinearity, and autocorrelation. Data analysis using multiple regression. The results are presented in Table 4.

Table 4. Multiple linear regression analysis results

\begin{tabular}{|c|c|c|c|c|c|c|}
\hline Model & Coefficient & t-statistic & Sig. & Keterangan & $\mathbf{R}^{2}$ & $\mathbf{F}$ \\
\hline Constant & 0.032 & 1.248 & 0.214 & & & \\
\hline Profitability & -0.857 & -5.043 & 0.000 & Significant & & \\
\hline Liquidity & 0.006 & 2.002 & 0.047 & Significant & 0460 & 47.681 \\
\hline Firm Size & 0.021 & 9.059 & 0.000 & Significant & 0.409 & (Sig. 0.00) \\
\hline Firm Age & 0.000 & 0.448 & 0.655 & Not Significant & & \\
\hline Leverage & -0.051 & -3.185 & 0.002 & Significant & & \\
\hline
\end{tabular}


Based on Table 4, it is known that the profitability and leverage coefficients are negative with sig. $<0.05$. The coefficient of liquidity and firm size is a positive with sig. $<0.05$. The firm age coefficient is positive with sig. $>0.655$. So it can be said statistically profitability and leverage negatively affect, liquidity and firm size positively affect IFR. Furthermore statistically, firm age has no effect on IFR.

F-value of regression model is 47,681 with sig. 0.000 . This indicates that the model has been fit and can be used to predict the influence of profitability, liquidity, firm size, firm age, and leverage toward IFR. The effect of these five variables on IFR was $\mathrm{R}^{2}(0.469$ or $46.9 \%)$.

Based on the results of the first hypotheses test (table 4 ) obtained a coefficient of negative value, t-test $(-5,043)<$ t-table $(1,655)$ with sig. $<0.05$. Statistical test results show that profitability has a negative effect on IFR. It means that companies with low profitability then the company will publish more information through IFR. Companies with low profitability make effort to maintain their reputation by increasing the disclosure of other financial information.

Companies with low profitability will make IFR disclosure more fully [13]. The disclosure aims to convince stakeholders and the public about the company's reputation. It is to improve their image or reputation (good news). Companies with low profitability actually have a responsibility to disclose more information. It is the need of creditors and shareholders. These results support previous research which has stated that profitability has a negative effect on IFR [12][13][45]. However, other studies have found profitability has a positive effect on IFR [9][34].

Table 4 shows that liquidity has a positive effect on IFR. The liquidity coefficient is positive, t-test $(2.002)>$ t-table $(1.655)$ with sig. $<0.05$. Thus companies with high liquidity then they will publish more information through IFR. Companies with high liquidity will be motivated to inform their financial statements in full and more through the internet. Consistent with theory of signals, companies with high liquidity will increasingly disclose information that becomes good news for the company. The company wants to share it through IFR [16].

These results were contrasted with Reskino and Sinaga [14], Aly et al. [12]. They stated that liquidity does not affect IFR. But these results supported Rizky and Ikhsan [16], Almtairi [43], and Oyelere et al. [41] stated that liquidity is positive for IFR.

The third hypotheses testing results (table 4 ) obtained a coefficient of positive value, t-test $(9,059)>$ t-table $(1,655)$ with sig. $<0.05$. These results indicate firme size positively affects IFR. It can be said that large companies will use IFR to publish more complete information. Large companies have quality management information systems (MIS). MIS supports in providing and publishing information through IFR [8]. The larger companies will disclose more information to satisfy the needs of investors [14].

Large companies have high complexity. Increased business targets and intense business competition. This will encourage the use of IFR with more complete information. it is to show the company's resources [14]. These results are different from Ginting et al. [11], Al-Asiry [38], Hosseinzadeh et al. [21] stated that firm size does not affect IFR. But the research was in line with Putri and Azizah [9], Budianto [20], Ebrahimabadi and Asadi [51], Monday and Nancy [52], Mangena and Tauringana [49]. They stated that firm size has a positive effect on IFR.

In table 4 , firm age coefficient is 0.000 , t-test $(-0448)<\mathrm{t}$-table $(1,655)$ with sig. $>0.05$. These results indicate that statistically, firm age does not affect IFR. Long-established companies do not ensure that they are willing to disclose more information to stakeholders. The company has experience in disclosing information that concerns them. Companies do not need to disclose all information but pay more attention to information desired by stakeholders 
[22]. These results are different from Reskino and Sinaga [14], Abdullah et al. [23], Harsanti et al. [24]. They stated that firm age was positive affect IFR. But these results are in line with Jannah [22]. She stated that firm age does not affect the IFR.

Based on the fifth hypotheses test result (table 4) known leverage coefficient is -0.051 , $\mathrm{t}$ test $(-3,185)<$ t-table $(1.655)$ with sig. $<0.05$. These results suggest that the leverage statistically negatively affects IFR. This means companies with high leverage further reduce information disclosure through IFR. Companies with high leverage show the high use of debt to fund companies. In signal theory, a high level of leverage can be a bad news signal for a company's performance. Companies with high leverage will reduce IFR disclosures. This aims to avoid the company's bad image [27]. These results differed from Miniaoui and Oyelere [34], Momany and Al-Shorman [56], Laswad et al. [60] which stated that the leverage has a positive effect on IFR. Oyelere et al. [41], Alarussi et al. [2], Aly et al. [12] who concluded the leverage does not affect IFR. However, this research was in line with Damaso and Lourenco [59], Maulana and Almilia [8], Diatmika, and Yadnyana [27] that argued leverage was negatively affected by IFR

\section{Conclusion}

Statistical test results has shown that profitability has negative effect on IFR. Companies with low profitability will strive to maintain their reputation. They will publish more complete information through the internet. IFR contains more information that the user needs. So users pay more attention than profitability. The second result has shown that liquidity has positive effect on IFR. Companies with high liquidity usually use IFR to disclose more information. Companies with high liquidity will be motivated to disclose more information that signals good news. That will enhance the company's reputation.

Firm size has positive effect on IFR too. Large companies, usually have management information system that makes it easy to disclose information through IFR. So that large companies will publish more information needed by investors or others. Furthermore, the result also has shown that statistically firm age has no effect on IFR. Older companies do not always want to disclose more information to stakeholders. Companies have experience in providing information that is of concern to stakeholders. They provide information in accordance with stakeholder needs. Finally, the results have shown that statistically leverage has a negative effect on IFR. Companies with high leverage mean that the use of debt to fund companies is also high. They will avoid disclosing information that can make a bad image (bad news).

This study cannot prove the effect of firm age on IFR. Profitability, liquidity, firm size, firm age, and leverage are only able to explain IFR of $45.2 \%$. Much more is not explained in this study. Therefore, further research must prove empirically about the effect of firm age on IFR. It needs to involve more samples. The research can also add other independent variables such as institutional ownership and auditor reputation.

\section{References}

[1] Kieso, D., Weygandt, J. and Warfield, T. 2016. Intermediate Accounting: IFRS Edition. John Wiley and Sons. USA. 
[2] Alarussi, A., Hanefah, M. and Selamat, M. 2009. Internet financial and environmental disclosures by Malaysian companies. Issues in Social and Environmental Accounting. Vol. 3(1):3-25.

[3] Rocha, A. 2012. Three-dimensional model for the global quality of a website. International Journal of Business Information Systems. Vol. 10(4):436-446.

[4] Al-Debei, M. 2014. The quality and acceptance of websites: an empirical investigation in the context of higher education. International Journal Business Information Systems, Vol. 15(2):170 188.

[5] Xiao, Z., Jones, M. and Lymer, A. 2002. Immediate trends in internet reporting. The European Accounting Review, Vol. 11, No. 2, pp.245-275.

[6] Desoky, A.M. 2009. Accounting in Emerging Economies. UK: Emerald Group Publishing Limited.

[7] Chen, Jason et al. 2013. Advances in Accounting Behavioral Research. UK: Emerald Group Publishing Limited.

[8] Maulana, I. R. and Almilia, L. S. 2018. Factors affecting the internet financial reporting (IFR) in banking sector companies listed on the Indonesia Stock Exchange (IDX). The Indonesian Accounting Review STIE Perbanas. Vol. 8(2): 175 - 187.

[9] Putri, M. N. A. and Azizah, D. F. 2019. Pengaruh ukuran perusahaan, leverage dan profitabilitas terhadap pelaporan keuangan melalui internet (internet financial reporting) (Studi pada perusahaan manufaktur sub sektor industri dan kimia yang terdaftar di Bursa Efek Indonesia periode 2017). Jurnal Administrasi Bisnis Universitas Brawijaya. Vol. 72(2): 205-213.

[10] Kurniawati, Y. 2018. Faktor-faktor yang berpengaruh pada internet financial reporting (ifr) di perusahaan manufaktur yang terdaftar dalam Bursa Efek Surabaya (BES). Media Mahardhika. Vol.16(2): 289-299.

[11] Ginting, W. A., Munawarah and Dini, S. 2019. Faktor-faktor pelaporan keuangan berbasis website dengan model regresi logistik. Jurnal Akuntansi dan Bisnis Universitas Prima Indonesia. Vol.5(1):1-8.

[12] Aly, D., Simon, J. and Hussainey, K. 2010. Determinants of corporate internet reporting: evidence from Egypt. Managerial Auditing Journal. Vol. 25(2):182-202.

[13] Keumala, N. N. and Muid, D. 2013. Analisis faktor-faktor yang mempengaruhi pelaporan keuangan perusahaan melalui website perusahaan. Diponegoro Journal Of Accounting. Vol. 2(3): $1-10$.

[14] Reskino and Sinaga. 2016. Kajian empiris internet financial reporting dan praktek pengungkapan. Media Riset Akuntansi, Auditing \& Informasi. Vol. 16(2): 86-107.

[15] Fahmi, Irham. 2013. Analisis Laporan Keuangan. Bandung: Alfabeta

[16] Rizki, F. and Ikhsan, A. E. 2018. Pengaruh rasio aktivitas, risiko sistemati, dan tingkat kepemilikan saham terhadap internet financial reporting (Studi pada perusahaan manufaktur yang terdaftar di Bursa Efek Indonesia periode 2011-2015). Jurnal Ilmiah Mahasiswa Ekonomi Akuntansi. Vol. 3(3): 443-458.

[17] Ramiati. dkk. 2013. Analisis faktor faktor yang mempengaruhi praktek penerapan internet financial reporting pada perusahaan manufaktur di Bursa Efek Indonesia. Jurnal Fakultas Ekonomi. Vol. 3(1): $1-13$.

[18] Leonardi, Lisa Agustina. dkk. 2014. Pengaruh ukuran perusahaan, profitabilitas, leverage, likuiditas, kepemilikan pihak luar dan umur listing terhadap pengungkapan internet financial and sustainability reporting (IFSR) pada perusahaan manufaktur yang listed di Bursa Efek Indonesia (BEI) Tahun 2009-2012. Jurnal Riset Manajemen dan Akuntansi. Vol. 02 No. 02 Hal. 68- 80.

[19] Khikmawati, I. and Agustina, L. 2015. Analisis rasio keuangan terhadap pelaporan keuangan melalui internet pada website perusahaan. Accounting Analysis Journal. Vol. 4(1): 1-8.

[20] Budianto. 2018. Pengaruh ukuran perusahaan, profitabilitas, reputasi auditor dan market activity terhadap internet financial reporting pada perusahaan manufaktur yang terdaftar di Bursa Efek Indonesia. Riset Akuntansi dan Bisnis. Vol.2(1): 13-27.

[21] Hosseinzadeh, G., Kangarlouei, S.J. and Morteza, M. 2014. Firms characteristic and firms disclosure quality in firms listed in Tehran Stock Exchange. International Journal of Marketing and Business Communication. Vol. 3(1), 20-28. 
[22] Jannah, R. 2015. Uji faktor-faktor yang mempengaruhi pengembangan pengungkapan melalui praktik pelaporan keuangan berbasis internet (internet financial reporting) (Studi empiris pada 100 perusahaan terkemuka di Indonesia). Jom FEKON Universitas Riau. Vol. 2(2): 1-15.

[23] Abdullah, M. D. F., Ardiansah, M. N. and Hamidah, N. 2017. The effect of company size, company age, public ownership and audit quality on internet financial reporting. Sriwijaya International Journal of Dynamic Economics and Business. Vol. 1 (2): 153-166.

[24] Harsanti, P., Mulyani, S. and Fahmi, N. 2014. Analisis determinan ketepatan waktu corporate internet reporting pada perusahaan yang terdaftar di Bursa Efek Indonesia. Jurnal Dinamika Ekonomi \& Bisnis. Vol. 11(1):32-45.

[25] Lestari, H. S. and Chariri, A. 2012. Analisis faktor-faktor yang mempengaruhi internet financial reporting dalam website perusahaan. Diponegoro Journal of Accounting. Vol.1(1): 1-13.

[26] Andriyani, R. and Mudjiyanti, R. 2017. Pengaruh tingkat profitabilitas, leverage, jumlah dewan komisaris independen dan kepemilikan institusional terhadap pengungkapan internet financial reporting (IFR) di Bursa Efek Indonesia. Kompartemen Jurnal Ilmiah Akuntansi. Vol. 15(1): 6781 .

[27] Diatmika, I G. P. A. and Yadnyana, I K. 2017. Pengungkapan pelaporan keuangan melalui website dan faktor-faktor yang mempengaruhi. E-Jurnal Akuntansi Universitas Udayana. Vol. 21(1): 330357.

[28] Yassin, M.M. 2017. The determinants of internet financial reporting in Jordan: financial versus corporate governance. International Journal of Business Information Systems. Vol. 25(4): 526-556.

[29] Wild, John J. 2013. Financial Accounting Fundamentals-Fourth Edition. Boston: Mc. Grow Hill.

[30] Gibson, C.H. 2012. Financial Reporting \& Analysis-Using Financial Accounting Information. South Western: Cengage Learning.

[31] Gitman, Lawrence J and Chad J. Zutter. 2015. Principles of Managerial Finance. USA: Pearson.

[32] Al-Htaybat, K. 2011. Corporate online reporting in 2010: a case study in Jordan. Journal of Financial Reporting \& Accounting. Vol. 9(1): 5-26.

[33] Henchiri, J.E. 2011. Voluntary web-based disclosures by Moroccan and Tunisian companies. EuroMed Journal of Business. Vol. 6(2): 155-173.

[34] Miniaoui, H. and Oyelere, P. 2013. Determinants of internet financial reporting practices: evidence from the UAE. Review of Pacific Basin Financial Markets and Policies. Vol. 16(4):1-25.

[35] Fathi, J. 2013. The determinants of the quality of financial information disclosed by French Listed Companies. Mediterranean Journal of Social Sciences. Vol. 4(2):319-336.

[36] Uyar, A., Kilic, M. and Bayyurt, N. 2013. Association between firm characteristics and corporate voluntary disclosures: evidence from Turkish non-financial listed firms. Journal of Intangible Capital. Vol.9(4): 1080-1112.

[37] Takhtaei, N., Mousavi, Z., Tamimi, M. and Farahbakhsh, I. 2014. Determinants of disclosure quality: empirical evidence from Iran. Asian Journal of Finance and Accounting. Vol.6(2): 422438.

[38] Al-Asiry, M. 2017. Determinants of quality of corporate voluntary disclosure in emerging countries: a cross national study. Doctoral Thesis- University of Southampton, 1-215.

[39] Ahmed, A., Billings, B., Morton, R. and Stanford-Harris, M. 2002. The role of accounting conservatism in mitigating bondholder - shareholder conflicts over dividend policy and in reducing debt costs. The Accounting Review, Vol. 77(4):867-890.

[40] Joshi, P. L., and Gao, S. 2009. Multinational corporations' corporate social and environmental disclosures (CSED) on websites. International Journal of Commerce and Management. Vol. 19(1): $27-44$

[41] Oyelere, P., Laswad, F., and Fisher, R. 2003. Determinants of internet financial reporting by New Zealand companies. Journal of International Management and Accounting, Vol. 14(1): 26-63.

[42] Marston, C., and Polei, A. 2004. Corporate reporting on the internet by German Companies. International Journal of Accounting Information Systems. Vol. 5: 285-311.

[43] Almtairi, G. 2012. Factors affecting the level of disclosure of financial information on the internet in the financial statements issued by Kuwaiti corporation. Master degree thesis. Middle East University. Jordan. 
[44] Pozniak, L. 2013. Internet financial communication: evidence from unregulated markets of Brussels and Paris. International Journal Of Business and Finance Research (IJBFR). Vol. 7(5): 107-122.

[45] Dyczkowska, J. 2014. Assessment of quality of internet financial disclosures using a scoring system: a case of Polish stock issuers. Accounting and Management Information Systems. Vol. 13(1):50-81.

[46] Debreceny, R., Gray, G. and Rahman, A. 2002. The determinants of internet financial reporting, Journal of Accounting and Public Policy. Vol. 21(4/5):371-394.

[47] Bozcuk, A. E. 2012. Internet financial reporting: Turkish companies adapt to change. Managerial Finance, Vol. 38(8):786-800

[48] Nurunnabi, M., and Hossain, M. A. 2012. The voluntary disclosure of Internet financial reporting (IFR) in an emerging economy: a case of digital Bangladesh. Journal of Asia Business Studies. Vol. 6(1): 17-42.

[49] Mangena, M. and Tauringana, V. 2007. Disclosure, corporate governance and foreign share ownership on the Zimbabwe Stock Exchange. Journal of International Financial Management and Accounting. Vol.18(2): 53-85.

[50] Agyei-Mensah, B.K. 2013. Adoption of international financial reporting standards (IFRS) in Ghana and the quality of financial statement disclosures. International Journal of Accounting and Financial Reporting, Vol.3(2):269-286.

[51] Ebrahimabadi, Z. and Asadi, A. 2016.The study of relationship between corporate characteristics and voluntary disclosure in Tehran Stock Exchange. International Business Management, Vol.10(7): 1170-1176.

[52] Monday, I.I. and Nancy, A. 2016. Determinants of voluntary disclosure quality in emerging economies: evidence from firms listed in Nigeria Stock Exchange. International Journal of Research in Engineering and Technology. Vol. 4(6): 37-50.

[53] Umoren, A. O. and Asogwa, I. E. 2013. Internet financial reporting and company characteristics: a case of quoted companies in Nigeria. Research Journal of Finance and Accounting. Vol. 4(12).

[54] Owusu-Ansah, S. 1998. The impact of corporate attributes on the extent of mandatory disclosure and reporting by listed companies in Zimbabwe. International Journal of Accounting. Vol. 33(5): 605-632.

[55] Owusu-Ansah, S. 2005. Factors influencing corporate compliance with financial reporting requirements in New Zealand. International Journal of Commerce and Management. Vol. 15(2): 141-157.

[56] Momany, M. and Al-Shorman, S. 2006. Web-based voluntary financial reporting of Jordanian companies. International Review of Business Research Papers. Vol. 2(2):129-139.

[57] Zare, R., Kiafar, H., Rasouli, F., Sadeghi, L. and Behbahani, S. 2013. Examining financial leverage, profitability and firm life influencing nonfinancial information disclosure quality. Acta Universitatis Danubius: Oeconomica. Vol. 9(6): 163-175.

[58] Boubaker, S., Lakhal, F. and Nekhili, M. 2012. The determinants of web-based corporate reporting in France. Managerial Auditing Journal. Vol. 27(2): 126-155.

[59] Damaso, G. and Lourenco, I. 2011. Internet financial reporting: environmental impact companies and other determinants. 8th International Conference on Enterprise Systems. Accounting and Logistics. Greece.

[60] Laswad, F., Fisher, R. and Oyelere, P. 2005. Determinants of voluntary internet financial reporting by local authorities. Journal of Accounting and Public Policy, Vol. 24(2):101-121. 